\title{
Determination of crude protein and metabolized energy with near infrared reflectance spectroscopy (NIRS) in ruminant mixed feeds
}

\section{Research Article}

Volume: 4, Issue: 2 August 2020

Pages: 31-36

\section{Article History}

Received: 19.04.2020 Accepted: 24.05 .2020 Available online: 26.05.2020

\section{Hasan Atalay $^{1} *$, Tanay Bilal ${ }^{2}$}

1. Department of Animal Nutrition and Nutritional Diseases, Faculty of Veterinary Medicine, Balikesir University 10145, Balıkesir, Turkey. ORCID ID. 0000-0002-5744-7538. 2. Department of Animal Nutrition and Nutritional Diseases, Faculty of Veterinary Medicine, Istanbul University-Cerrahpasa, 34320, Istanbul, Turkey. ORCID:00000001-7258-6862

\section{ABSTRACT}

This study aims to determine the crude protein and metabolizable energy values in ruminant mixed feeds based on the measurements obtained from Near Infrared Reflectance Spectroscopy (NIRS) device. The mixed feeds used in the study were produced in Balıkesir. Reference analyses were determined by making chemical analyses of mixed feed samples used in the study. Metabolic energy value of mixed feed samples was calculated by using the determined nutrient values in equations. Portable NIRS device was used in the study. The relationship between estimates obtained from NIRS device and reference values was statistically evaluated. In regression analysis, R2 value was found as 0.0064 for crude protein while it was 0.9397 for metabolizable energy. It has been demonstrated that the NIRS method is a fast, reliable and good estimation method for quantitatively determining the metabolic energy value in ruminant mixed feeds.

Keywords: mixed feed, metabolizable energy, near infrared reflectance spectroscopy (NIRS)

DOI: https://doi.org/10.30704/http-www-jivs-net.723231

To cite this article: Atalay, H., \& Bilal, T. (2020). Determination of crude protein and metabolized energy with near Infrared reflectance spectroscopy (NIRS) in ruminant mixed feeds. Journal of Istanbul Veterinary Sciences. 4(2), 3136, Abbreviated Title: J Ist Vet Sci

\section{Introduction}

Energies are transformed into one form to another in our lives. Green plants store the physical energy of the sun by converting it into chemical energy. Humans and animals transform chemical energy in plants into biochemical energy (ATP) by biochemical reactions (oxidation). Energy is not wasted, instead offered to people to use. Energy which is an abstract concept can be simply defined as the ability of the body to work. There are various forms of energy and these forms can be

transformed into heat energy. However, heat energy cannot be transformed into other forms of energy. The chemical energy (gross energy) in the feed can be determined by the heat energy released as a result of the burning of the feed substance in the calorimetry bomb. Metabolizable energy is obtained by removing the energies of feces, urine and fermentation gases (methane) from gross energy (Kirchgessner, 1985).

*Corresponding Author: Hasan Atalay

E-mail: hasanatalay@balikesir.edu.tr 
Many chemical analyses are used to estimate the quality of mixed feeds and their relationship to animal performance. Neutral Detergent Fiber (NDF) and Acid Detergent Fiber (ADF) analyses recommended by Van Soest are chemical analyses that are obtained using the in vitro technique and used to predict dry matter intake (DMI) and digestible dry matter (DDM). In these analyses, the organic parts of the plants are divided into two as intracellular components (lipids, sugars, organic acids, starch, non-protein nitrogen, soluble protein, pectin and soluble matter) and cell wall components (hemicellulose, cellulose, lignin, lignified $\mathrm{N}$ compounds, keratin, silica, heat damaged protein) according to the chemical detergents (Rohweder et al., 1978).

In plants, carbohydrates are divided into two as structural and non-structural carbohydrates. Structural carbohydrates on cell wall are pectin, $\beta$ -glucan, galactosides, arabinoxylan (pentosan), hemicellulose, cellulose, and lignin, whereas nonstructural carbohydrates in the cell are organic acids, starch, and sugars. Carbohydrates are produced by photosynthesis and stored in plants. Carbohydrates in plants consist of cell content (sugars and starch) and cell wall elements (cellulose, hemicellulose, lignin). Starch is highly found in grain feeds while cellulose is found in roughages in high density. Starch and cellulose are glucose molecules linked by different chemical bonds. Starch is digested with enzymes in the digestive system, and cellulose is digested with enzymes produced by microorganisms in the digestive system. Hemicelluloses are also digested by microorganisms in the digestive system and transformed into organic acids used as the main energy source of the organism. The biggest component of the plant cell wall is cellulose. It is a glucose polymer combined with a $\beta-1,4$ glycoside bond. Hemicellulose is a heterogeneous polysaccharide (galactose, arabinose) with 5 and 6 carbons such as xylose, glucose and combined with $\beta-1,4$ glycoside bond. Lignin is not a carbohydrate, but a phenol alcohol polymer. Microorganisms found in rumen break down cellulose in the feed with the enzymes they synthesize, and thus essential fatty acids, carbon dioxide and methane gas are generated and energy is obtained (Tekce and Gül, 2014).

The cell wall components are digested by fermenting the feed cell wall with the enzymes produced and secreted by the cellulotic bacteria in the rumen. Cellulotic bacteria rapidly break down the water-soluble sugar, starch and pectin, that is, the cell content of the feed. However, hemicellulose breaks down the cell wall components of the water-insoluble slowly and the cellulose breaks down them even more slowly. Lignin is not a carbohydrate, and it cannot be broken down by cellulotic bacteria (Van soest, 1994; Yavuz, 2005).

Carbohydrates constitute the main component of Ruminant rations and are divided into two as structural (cellulose, hemicellulose) and non-structural (starch, sugar) carbohydrates. It is effective on milk fat of structural carbohydrates, acetic acid / propionic acid ratio in rumen, dry matter consumption, rumen $\mathrm{pH}$, saliva amount and chewing activity (Özen et all, 2005; Saçaklı et all 2007).

The higher roughage is in the ration, the higher acetic acid is produced. The higher protein is, the higher butyric acid is created. And the higher mixed feed is, the higher propionic acid occurs. Acetic acid and butyric acid form milk synthesis and milk fat. Propionic acid provides energy. Cellulotic bacteria are active between $\mathrm{pH}$ 6.2-6.8 but are inactive below $\mathrm{pH}$ 6. Amylotic bacteria that provide starch digestion are active between Ph 5.2-6.08 (Li et al., 2012).

Near Infrared Analysis is a method used by the feed industry to evaluate the nutrient content of feeds. Near-infrared reflection spectrophotometer is a fast, quick and chemicalfree computerized analysis method used to analyze the nutrient content of forage crops and other feedstuffs. Traditional analysis methods are expensive and time-consuming as wet chemicals are used. Since this method uses infrared light instead of chemical, it has low cost and is more environmentally friendly. In the near infrared analysis, the feed sample is exposed to the infrared light source in the spectrophotometer. The reflected infrared light is transformed into 
electrical energy and transferred to the computer. The nutrient content of the feed absorbs and reflects near infrared light. Different organic components in feeds can be measured with these different lights reflected in spectrophotometry and each different organic component in a feed can be calculated. The calculation of the reflection of nutrients in the feeds analyzed by chemical methods in spectrophotometry with a computer program constitutes the NIRS analysis. After a feed is placed in the NIRS device, the device compares the wavelength reflections from the feed and matches them from the sample library containing the pre-analyzed feed items and determines the nutrient content (Richard and Church, 2010).

The ability to measure nutrient components (protein, fat) in the feedstuff in NIRS analysis is related to the energy movement of the hydrogen bond. The chemical bonds formed by the hydrogen in the nutrient with other atoms ($\mathrm{CH},-\mathrm{OH},-\mathrm{NH},-\mathrm{SH}$ ) absorb energy at specific wavelengths and change the wavelengths (radiation intensity) reflected from the nutrient. The principle of the NIRS analysis is based on the absorption of electromagnetic radiation of near infrared light in the feed material. The radiation reflected from the feed is measured in the energy detector. The electromagnetic wavelength of NIRS is between 700-3000 nm. The analysis is usually performed between 1100 $2500 \mathrm{~nm}$ wavelength (Ünal, 2005).

This study aims to investigate whether it is possible to determine the crude protein and metabolizable energy values of ruminant mixed feeds by using NIRS analysis. Although analysis with NIRS has advantages such as being very fast and not using chemicals, calibration to the device is an important disadvantage that requires advanced knowledge and experience to overcome.

\section{Materials and methods}

Reference Analysis (Chemical Analysis): Examples of ruminant mixed feed used in the study are produced in Balıkesir. $0.5 \mathrm{~kg}$ fresh mixed feed samples ( $n: 10)$ were taken from the feed factories and brought to the laboratory in air-tight bags and kept at $-20^{\circ} \mathrm{C}$ until analysis. Feed samples were milled in the Retsch ZM 200 ultra centrifugal mill in a $1 \mathrm{~mm}$ screen for analysis. The reference analyses (chemical analyses) of the feeds used in the study were carried out according to the methods reported in Balıkesir University, Faculty of Veterinary Medicine, the laboratory of Animal Nutrition and Nutritional Diseases as the crude protein method 990.03, crude cellulose method 962.09, crude oil method 920.39 (AOAC, 1997). Metabolizable energy values were calculated according to the metabolic energy formula in the ruminant mixed feeds reported the Turkish Standards Institute (Türk Standartlar Enstitüsü, 1991) and given below.

$\mathrm{ME},(\mathrm{kcal} / \mathrm{kg} \mathrm{OM})=3260+\left(0,455^{*} \mathrm{HP}\right)-$ $(4,037 * \mathrm{HS})+(3,517 * \mathrm{HY})$

$\mathrm{OM}=$ Organic matter

$\mathrm{CP}=$ Crude Protein, $\mathrm{g} / \mathrm{kg} \mathrm{OM}$

$\mathrm{CS}=$ Crude Cellulose, $\mathrm{g} / \mathrm{kg} \mathrm{OM}$

$\mathrm{CF}=$ Crude Fat, $\mathrm{g} / \mathrm{kg}$ OM

NIRS Spectroscopy Measurements: Spectral measurements of ruminant mixed feed samples were conducted on a portable NIRS device (Dinamica Generale Agri NIR Analyzer, Italy). Using the ready and defined calibration set in the Portable NIRS Device, crude protein, crude oil and crude cellulose data were taken, and these data were calculated in the metabolizable energy formula Turkish Standards Institute, 1991 (Türk Standartlar Enstitüsü, 1991) and metabolizable energy values of mixed feeds were calculated.

Statistical Analysis: The data obtained from the study were analyzed with the SAS (SAS Institute, 1999). statistical software package.

\section{Results and Discussion}

Descriptive statistics for reference analysis for crude protein and metabolizable energy of ruminant mixed feed are given in Table 1 . In Table 2, Wilcoxon test results for reference and NIRS analysis are given for crude protein and metabolizable energy. The differences between reference analyses for crude protein and ME and 
Table 1. Descriptive statistics regarding reference analysis of crude protein and metabolizable energy

\begin{tabular}{lll}
\hline & Crude protein & Metabolizable energy \\
\cline { 2 - 3 } $\mathrm{n}$ & 10 & 10 \\
\hline Mean & 17.94 & 3237.7 \\
Min & 15.62 & 3224.0 \\
Max & 23.73 & 3264.5 \\
Standard Deviation & 2.38 & 12.4 \\
\hline
\end{tabular}

Table 2. Wilcoxon test results for crude protein and ME

\begin{tabular}{lllll}
\hline Trait & Group-Comp & Diff & $P$ value & Significance \\
\hline Crude Protein & Ref-NIR & -2.42 & 0.00617 & $* *$ \\
ME & Ref-NIR & -7.18 & 0.161 & ns \\
\hline
\end{tabular}

NIRS estimates are shown in Figure 1. It was observed that the mean of NIRS estimates for crude protein ratio was significantly higher than the reference analysis results. Although the mean of the NIRS estimates for the ME value was higher than the reference analyses, the difference between the two groups was not statistically significant. Figure 2 shows the results of the regression analysis between the reference analysis of the crude protein and metabolizable energy values and the NIRS results.

In their study, Çelik et al. determined metabolized energy values of dairy cattle and beef cattle as 2549 and $2541 \mathrm{kcal} / \mathrm{kg}$ OM, respectively (Çelik et al., 2003). Baran et al. found metabolized energy values of dairy cattle and beef cattle as 2667 and $2673 \mathrm{kcal} / \mathrm{kg} \mathrm{OM}$, respectively (Baran et al., 2008a).
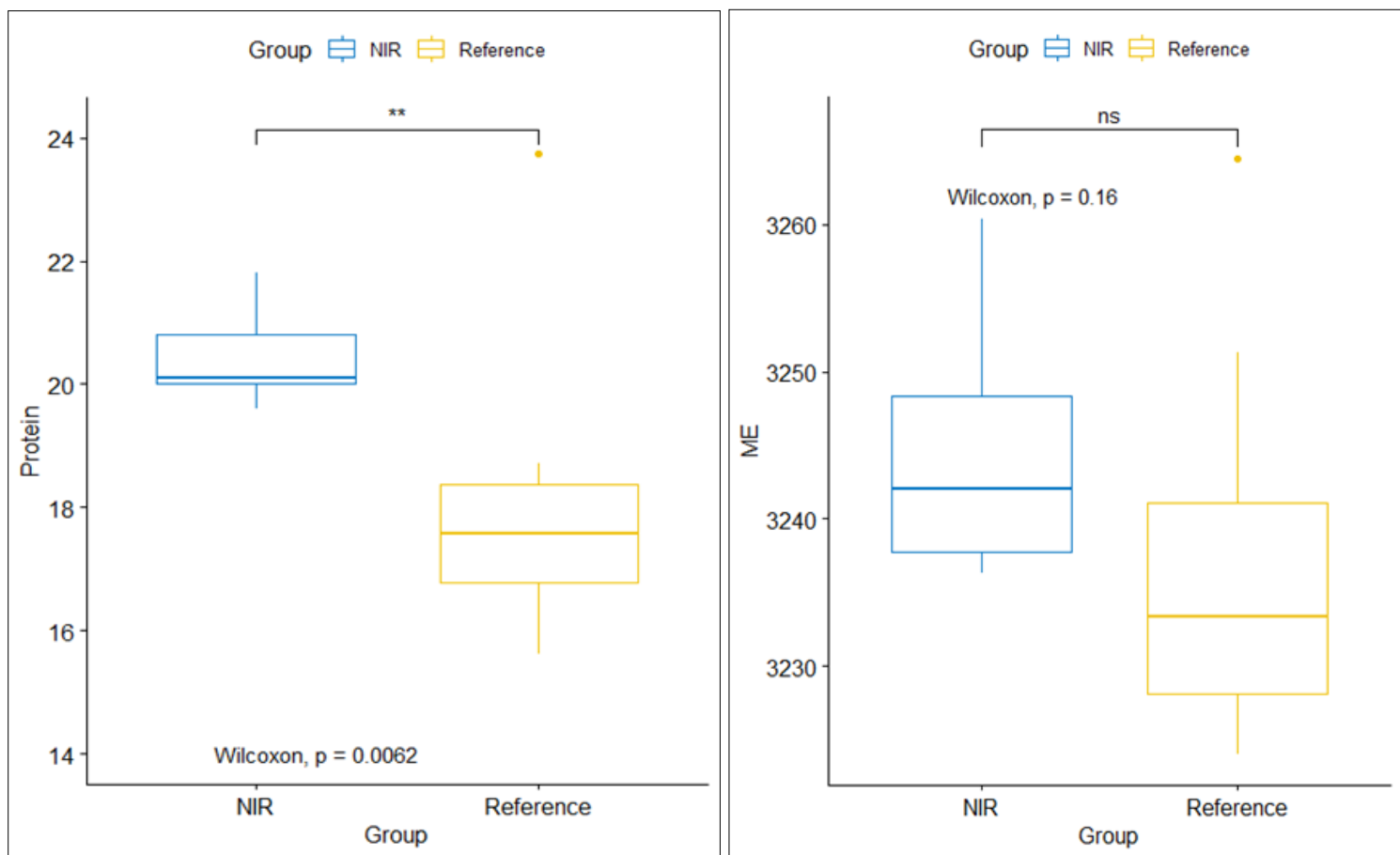

Figure 1. Differences between reference analysis and NIR estimates for crude protein ratio and Metabolizable energy value 


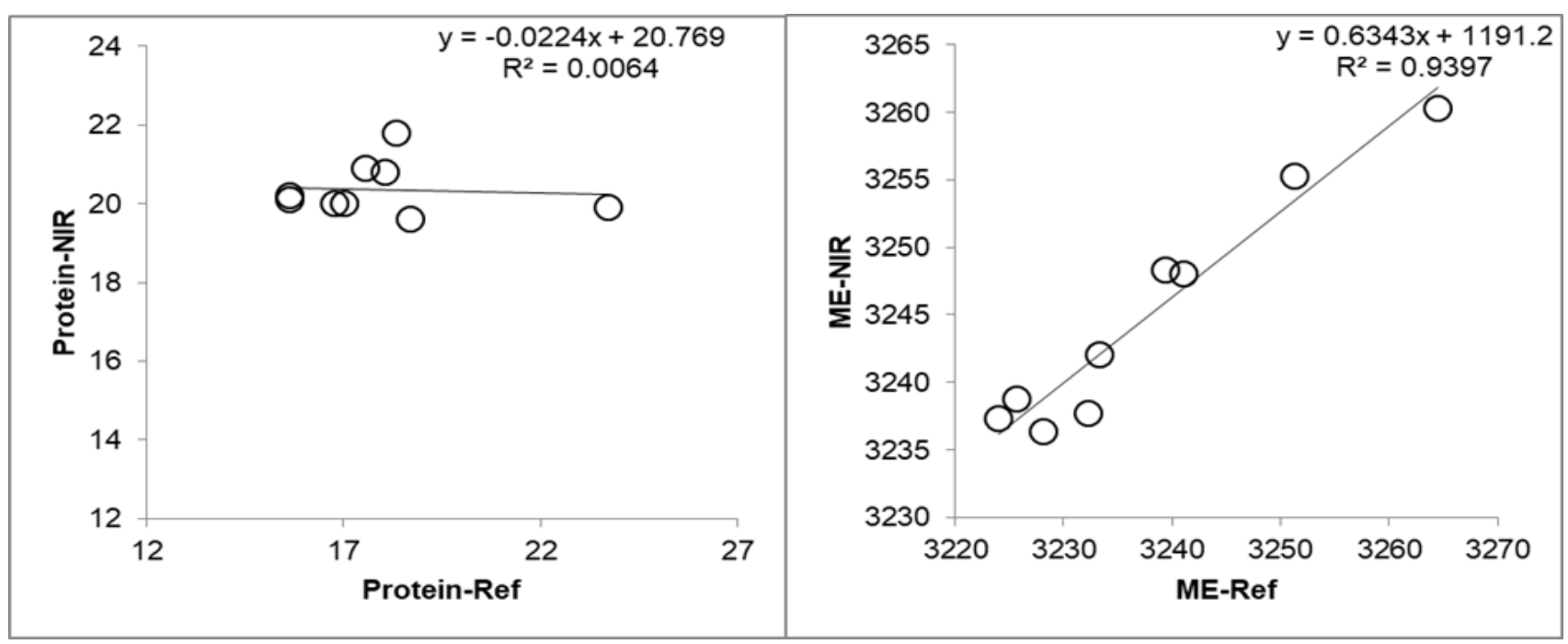

Figure 2. Regression analysis between reference analysis and NIR results of crude protein and metabolizable energy values.

Baran et al., also found crude protein values in dairy cattle and beef cattle as $14.81 \%$ and $13.17 \%$, respectively (Baran et al., 2016). In their study, Baran et al., obtained crude protein values in dairy cattle) and beef cattle as $15.13 \%$ and $12.60 \%$, respectively (Baran et al., 2008a). In the study conducted by Baran et al., the crude protein values of dairy cattle and beef cattle were $14.39 \%$ and $13.10 \%$, respectively (Baran et all., 2008b). In the thesis study conducted by Gündüz, 2013 crude protein value in milk feed was shown to be 21.26 \% (Gündüz, 2013).

NIRS calibrations have been reported as accurate enough to estimate moisture, crude protein, crude fat, crude fiber and energy content in ruminant mixed feeds (Boover et al., 1995), which is similar to our results.

It has been stated that accurate NIRS estimates can be obtained for crude protein,

\section{References}

AOAC (1997). Association of Official Analytical Chemists, 16th ed. Washington, D.C. USA.

Baran, M. S., Demirel, R., Şentürk Demirel, D., Şahin T., \& Yeşilbağ D. (2008a). Determination of the feding values of feedstuffs and mixed feeds in the Southeastern Anatolia Region of Turkey. Turkish Journal of Veterinary and Animal Sciences, 32(6), 449-455. ether extract, crude fiber, acid detergent fiber, neutral detergent fiber and gross energy in ostrich total mixed ratios (TMRs). It has been also expressed that less accurate NIRS estimates can be obtained for dry matter, ash, calcium and phosphorus in Ostrich TMRs (Swart et al., 2012). Those results are compatible with our study.

\section{Conclusion}

As a result, although analysis with NIRS has advantages such as being very fast and not using chemicals, there are important disadvantages of analyzing with NIRS, such as the cost of the device and requiring advanced knowledge and experience for calibration. It has been demonstrated that the NIRS method is a fast, reliable and good estimation method for quantitatively determining the metabolic energy value in ruminant mixed feeds.

Baran, M. S., Erkan, M. E., \& Vural A. (2008b). The nutrient values and microbiological quality properties of mixed feeds used in ruminant nutrition in Diyarbakir province, Journal of The Faculty of Veterinary Medicine Istanbul University, 34(1), 9-19.

Baran, M. S., Altaçli, S., Kaplan, O., \& Deniz S. (2016, 28 September-01 October). Diyarbakır'da ruminant beslemede kullanılan karma yemlerin 
besin değeri, sindirilebilirlik ve enerji içeriklerinin in vitro yöntemlerle belirlenmesi. Paper presented at the 1. International Animal Feding Congress, Antalya, Turkey.

Boover, J. L., Cottyn, B. G., Vanacker, J. M., \& Boucque, Ch. V. (1995). The use of NIRS to predict the chemical composition and energy value of compound feeds for cattle. Animal Feed Science and Technology, 51, 243-253.

Çelik, K., Ertürk, M. M., \& Ersoy, I. E. ( 2003). Farklı yem fabrikalarından örneklenen karma yem ve yem ham maddelerinde bazı kalite ögelerinin kantitatif araştırılması. Akdeniz Üniversitesi Ziraat Fakültesi Dergisi, 16(2), 161-168.

Gündüz, Y. (2013). İşletme koşullarında kullanılan bazı yemlerin besin madde kompozisyonu ve mikrobiyolojik özellikleri, Master thesis, Tekirdağ Namık Kemal University, Tekirdag, Turkey.

Kirchgessner, M. (1985). Hayvan besleme. öğretim, öğrenim ve uygulama önerileri. Translated Ed. Kılıç, A. Ankara, Turkey, TÜBITAK .

Li, R. W., Wu, S., Baldwin, R. L., Li, W., \& Li, C. (2012). Perturbation dynamics of the rumen microbiota in response to exogenous butyrate. PlosOne, 7, e29392.

Özen, N., Kirkpinar, F., Özdoğan, M., \& Ertürk, M. M., Yurtman, I. Y. (2005, January 3-7). Paper presented at the Hayvan besleme. Türkiye ziraat mühendisliği VI. teknik kongresi, Ankara, Turkey.

Richard, O. Kellems, D. C. Church (2010). Livestock feeds and feding. Translate ed. Alp, M., Kocabağll, N. İstanbul, Turkey: Nobel press.
Rohweder, D. A., Barnes, R. F., \& Jorgensen, N. (1978). Proposed hay grading standards based on laboratory analyses for evaluating quality. Journal of Animal Science, Volume, 47(3), 747759.

Saçaklı, P., Köksal, B. H., \& Tuncer, Ş. D. (2007). Süt ineklerinin beslenmesinde karbonhidratlar. Yem magazin, 48, 43-48.

SAS Institute, (1999). SAS V8 User Manual, SAS Cary, NC, USA, 1999.

Swart, E., Brand, T. S., \& Engelbrecht, J. (2012). The use of near infrared spectroscopy (NIRS) to predict the chemical composition of feed samples used in ostrich total mixed ration. South African Journal of Animal Science, 42(5). 550554.

Tekce, E., \& Gül, M. (2014). The importance of NDF and ADF ruminant nutrition. Atatürk University Journal of veterinary Science 9(1), 6373.

Turkis standart Instutue (1991). Animal feedsmetabolic energy determination. Ankara. Turkey: TSE Press.

Ünal, Y. (2005). The Use of Near Infrared Reflectance Spectroscopy in Animal Nutrition Science) (A REWiEW) Lalahan Hay. Araşt. Enst. Derg. 45 (1) 33-39.

Van Soest, P. J. (1994). Nutritional ecology of the ruminant (2nd Ed.) Ithaca, NY, USA: Cornell University Press.

Yavuz, M. (2005). Detergent fiber system. Gaziosmanpaşa Üniversitesi Ziraat Fakültesi Dergisi , 22(1), 93-93. 